\title{
Intercalation of Rhodamine B into Calf Thymus DNA in presence and absence of olive leaf extract: A fluorescence study
}

\begin{abstract}
Aqueous olive leaf extract (AOLE) of the Mediterranean tree Olea europaea is stated to have several therapeutic properties including: antifungal, antimicrobial, hypotensive and hypoglycemic actions as well as to use in treatment of some cancer cases as breast, skin and pancreatic cancers. Experimentally, the olive leaf extract is capable to protect nuclear calf thymus and human genomic DNA in vitro to Rhodamine B toxicity. Thus, this study was aimed to evaluate the protective effect of AOLE against toxic DNA damage induced by Rhodamine B using different techniques as UV-VIS Spectroscopy and fluorometry. Genomic DNA was used in a concentration of $75 \mu \mathrm{g} /$ ml. DNA was extracted from peripheral lymphocytes of anticoagulated blood (EDTA) samples by Proteinase K digestion and phenol/chloroform extraction. Dried leaves of Olea europaea (from West part of Libya) were grinded with distilled water; the resulting aqueous solution was then filtered and used. The protective effect of the AOLE was evaluated for its ability to decrease the amount of Rhodamine B available for binding with double stranded DNA. Thus, DNA resulted in a significant decrease in fluorescence intensity of Rhodamine B. Comparing to control samples, pre- and post-treatment with AOLE, significantly attenuated the binding ability of Rhodamine $\mathrm{B}$ to the DNA $(\mathrm{p}<0.01)$. Treatment with $5 \mathrm{~g} / 15 \mathrm{ml}$ of AOLE was enough to prevent Rhodamine B toxicity to the DNA. The cytoprotective and antioxidant properties were detected in AOLE by a fluorescence method. The antioxidant activity of AOLE was evaluated using the 2,2-diphenyl-1-picrylhydrazyl (DPPH) assay and the $\mathrm{IC}_{50}$ was $65 \pm 2.3 \mu \mathrm{g} / \mathrm{ml}$. In conclusion, this study suggests that AOLE induced a genoprotective effect by increasing the antioxidant capacity and the chemical interaction between Rhodamine B and constituents of AOLE.
\end{abstract}

Keywords: Rhodamine B, olive leaf extract, ctDNA, genomic DNA, genoprotective
Volume 6 Issue 2 - 2018

\author{
Alla M Hashkel,' Inass A Al-Sadawe,' Haneen \\ M Attayeb,' Asia A Almakhlufi,' Nesren \\ H Moagel,' Ibrahim A Mrema,' Salah M \\ Bensaber,' Fathi M Sherif, ${ }^{2}$ Anton Hermann, ${ }^{3}$ \\ Abdul M Gbaj' \\ 'Department of Medicinal Chemistry, University of Tripoli, Libya \\ ${ }^{2}$ Department of Pharmacology, University of Tripoli, Libya \\ ${ }^{3}$ Department of Cell Biology and Physiology, University of \\ Salzburg,Austria
}

Correspondence: Abdul M Gbaj,Associate professor of Genetics and Biochemistry, University of Tripoli, Tripoli, Libya, Tel +21891 355 6785, Email abdulgbajl@hotmail.com

Received: January 21, 2018 | Published: March 30, 2018
Abbreviations: RB, Rhodamine B; AOLE, aqueous olive leaf extract

\section{Introduction}

Interaction of small organic molecules with DNA has become an essential subject of medical research. Numerous attempts have been established by research groups to discover agents with a new therapeutic potential. ${ }^{1,2}$ Binding studies of various polyaromatic ligands to DNA have become a very promising exploration due to its relation to genetic effects and carcinogenicity. ${ }^{3,4}$ DNA interacting agents have exceptional been valuable in cancer biology due to their ability of therapeutic use. Many of presently used planar molecule anticancer agents exert their effect by interacting with DNA. Because of such reasons, characterization of the interaction of small molecular ligands as Rhodamine B (RB) with DNA has been the subject to some studies. ${ }^{5,6} \mathrm{RB}$ is widely used for industrial purposes including printing and coloring of textiles, papers, paints, leathers etc. In addition, RB, a common dye of the Rhodamine family, has extensively been used by researchers due to its biological importance..$^{7-9}$ In molecular biology, $\mathrm{RB}$ is known as an intercalating agent and has been used as a nucleic acid stain. Due to its exceptional structure, it can easily intercalate into the DNA double strand. When RB is exposed to light, it can form reactive oxygen compounds. There are two types of reactions resulting in the formation of reactive oxygen compounds. The first increases the energy of $\mathrm{RB}$ being transferred to biomolecules to form reactive oxygen compounds. In a second reaction, the energy is transferred to molecular oxygen to form singlet oxygen. ${ }^{10}$ When RB enters the body together with food, it may trigger oxidative stress on ovarian follicles and decreases the number of primary, secondary and de Graaf follicles. ${ }^{11}$ The main three-ring part of RB resembles a flat purine-pyrimidine base pair and can slide into DNA between adjacent co-planar base pairs (intercalation). ${ }^{12}$ In terms of thermodynamics, the formation constant of the Rhodamine B-DNA complex occurs spontaneously which has negative enthalpy and positive entropy. The negative enthalpy change is due to the binding of RB to the groove of DNA and the positive entropy change is due to release of the bound water from the DNA that is replaced by the binding of RB to DNA. ${ }^{12}$

In in vitro studies, Oleuropein, the major phenolic secoiridoid in Olea europaea L. (Oleaceae), has been described as a potent antioxidant ${ }^{13}$ and in vivo ${ }^{14}$ studies. Olive leaves or oleuropein have been shown to modulate cardiac, hepatic and metabolic conditions in high-carbohydrate, high-fat-fed rats ${ }^{14}$ and protect heart function against ischemia and reperfusion. ${ }^{15}$ Cumaoglu et al. ${ }^{16}$ showed that ethanolic extracts of olive leaves, oleuropein or hydroxytyrosol have protective and regenerative effects on redox balance and related signaling pathways in insulin releasing pancreatic $\beta$-cells exposed to hydrogen peroxide or a cytokine cocktail. ${ }^{17}$ In addition, Bali et 
al. ${ }^{18}$ have studied the ability of olive leaf extracts or polyphenolic compounds (oleuropein, hydroxytyrosol and quercetin) to protect $\mathrm{H}_{9} \mathrm{c}_{2}$ cardiomyocytes in vitro against 4-hydroxynonenal stress-induced toxicity and apoptosis. In the present study, it was aimed to examine the oligoprotective (genoprotective) properties of aqueous olive leaf extract (AOLE), which is a cost-effective herbal treatment with wellknown benefits, hoping to be used either alone or in combination with other medication such as $\mathrm{N}$-acetylcystein and pirfenidone to protect the DNA from damage by harmful agents.

\section{Materials and methods}

Genomic DNA was used in a concentration of $75 \mu \mathrm{g} / \mathrm{ml}$. DNA was extracted from peripheral lymphocytes of anticoagulated blood (EDTA) samples by Proteinase K digestion and phenol/chloroform extraction. The purity was determined by measuring the absorbance at $260 / 280 \mathrm{~nm}$ indicating that the sample is free from protein contamination. ${ }^{19}$ Calf thymus (CT) DNA was obtained from SigmaAldrich (St. Louis, MO, USA). The concentration was assayed spectrophotometrically using $6600 \mathrm{M}^{-1} \mathrm{~cm}^{-1}$ as a molar extinction coefficient at $260 \mathrm{~nm}$. The results were expressed in terms of basepair equivalents per $\mathrm{dm}^{3} \cdot{ }^{30} \mathrm{RB}$ was obtained from Hopkin \& Williams Ltd (London, UK) and was used without further purification. All the experiments were conducted in Tris buffer $(0.01 \mathrm{M}$ Tris, $0.1 \mathrm{M} \mathrm{NaCl}$, at $\mathrm{pH}$ 7.34). Glass-distilled deionized water and analytical grade reagents were used throughout all the experiments. The $\mathrm{pH}$ values of solutions were measured with a calibrated Jenway $\mathrm{pH}$-meter model 3510 (Staffordshire, UK). All buffer solutions were filtered through Millipore filters (Millipore, UK) of $0.45 \mathrm{~mm}$ pore diameter.

Absorbance spectra: Absorbance spectra were measured on a Jenway UV-visible spectrophotometer, model 6505 (London, UK) using quartz cells of $1.00 \mathrm{~cm}$ path length. A concentration of $0.24 \mu \mathrm{M}$ for RB was chosen for all absorption and emission measurements. This concentration was high enough to get good fluorescence signal strength in all the samples, and low enough to avoid possible aggregating of molecules, or other molecular effects that might affect the absorption and emission characteristics. In addition, RB has a somewhat a weaker signal which photo bleaches more easily and $0.24 \mu \mathrm{M}$ was found experimentally to be good enough to give a good signal with limited noise.

Fluorescence spectra: Fluorescence emission and excitation spectra were measured using Jasco FP-6200 spectrofluorometer (Tokyo, Japan) using fluorescence 4 -sided quartz cuvettes of $1.00 \mathrm{~cm}$ path length. The automatic shutter-on function was used to minimise photo bleaching of the sample. System A formation was induced by sequential addition of aliquots of $1790 \mu 1$ Tris buffer, $10 \mu 1 \mathrm{RB}$ (stock solution of $48 \mu \mathrm{M}), 100 \mu \mathrm{l}$ ct-DNA or genomic DNA from stock solutions $(1.5 \mathrm{mg} / \mathrm{ml})$ and finally $100 \mu \mathrm{l}$ of AOLE $(5 \mathrm{~g} / 15 \mathrm{ml})$. System B formation was induced by sequential addition of aliquots of $1790 \mu \mathrm{l}$ Tris buffer, $10 \mu \mathrm{l} \mathrm{RB}$ (stock solution of $48 \mu \mathrm{M}$ ), $100 \mu \mathrm{l}$ of AOLE, and finally $100 \mu \mathrm{l}$ ct-DNA or genomic DNA from stock solutions $(1.5 \mathrm{mg} /$ $\mathrm{ml}$ ). Emission spectra were recorded for each system using excitation wavelengths of maximum fluorescence intensity determined for the systems to be $550 \mathrm{~nm}$ using a slit width of $5 \mathrm{~nm}$ to examine alterations in emission spectra resulting from the complex construction of both systems. On construction of the full systems, the system was allowed to equilibrate for 2-5 minutes at room a temperature and emission spectra $(560-650 \mathrm{~nm})$ were recorded to monitor changes in $\mathrm{RB}$ intensity.

Stoichiometric studies of RB and AOLE: The binding stoichiometry was determined using fluorescence techniques. ${ }^{21}$ Fluorescence emission intensity of RB was monitored at $578 \mathrm{~nm}$ after exiting at $\lambda_{550} \mathrm{~nm}$ at room temperature. The fluorescence intensities were recorded in solutions where the concentration of RB was kept constant $(0.24 \mu \mathrm{M})^{11}$ and the concentration of AOLE varied. Differences in fluorescence intensity at $576 \mathrm{~nm}$ of RB in the absence and presence of AOLE were plotted against different volumes of AOLE. Data reported are averages of at least three experiments.

\section{Preparation of aqueous Olea europaea leave extracts}

Leaves of Olea europaea were collected from the Novellien zone, Tripoli, Libya in November 2017. The leaves (5gm) were cleaned and washed with distilled water and dried at a room temperature of $25^{\circ} \mathrm{C}$ for about 20 minutes. Dried leaves were grinded in a homogenizer (HO4A Edmund Buhler GmbH, UK) along with $15 \mathrm{ml}$ of distilled water, the resulting aqueous solution was then filtered using a Millipore filter $(0.45 \mu \mathrm{m}$ GHD Acrodisc GF, UK).

\section{Determination of the total phenolic content of Olea europaea}

The total phenolic contents of the aqueous Olea europaea was determined using the Folin Ciocalteau reagent. ${ }^{22}$ A calibration curve was plotted by mixing $1 \mathrm{ml}$ aliquots of $25,50,100,150,225,250$, $290,350,390$ and $450 \mathrm{mg} / \mathrm{ml}$ Gallic acid solutions with $5.0 \mathrm{ml}$ of Folin Ciocalteu reagent (diluted tenfold) and $4.0 \mathrm{ml}$ of sodium carbonate solution $(75 \mathrm{~g} / 1)$. The absorbance was measured after thirty min at $765 \mathrm{~nm}$. After one hour, the absorbance was measured to determine the total phenolic contents.

\section{Free Radical Scavenging Activity}

Free radical scavenging activity of AOLE extracts was measured by 2,2-diphenyl-1-picrylhydrazyl (DPPH) assay. In brief, $0.1 \mathrm{mM}$ solution of DPPH in ethanol was prepared. This solution $(1 \mathrm{ml})$ was added to $3 \mathrm{ml}$. of AOLE in ethanol at different concentration. The mixture was shaken vigorously and allowed to stand at room temp for $30 \mathrm{~min}$. then, absorbance was measured at $517 \mathrm{~nm}$. by using spectrophotometer (Jenway UV-visible spectrophotometer). ${ }^{23}$ A reference standard compound being used was ascorbic acid and experiment was done in triplicate. The IC50 value of the AOLE, which is the concentration of sample required to inhibit $50 \%$ of the DPPH free radical, was calculated0. The percent DPPH scavenging effect was calculated by using following equation: DPPH scavenging effect $(\%)$ or Percent inhibition $=A_{0} * A_{1} / A_{0} \times 100$. Where $A_{0}$ was the Absorbance of control reaction and $A_{1}$ was the Absorbance in presence of test or standard sample. ${ }^{23}$

\section{Melting curve experiments of Olea europaea leave extracts components with DNA}

$T_{m}$ experiments were performed spectrophotometrically (using Peltier-thermostatted cuvette holder in a Cary 4000 UV-visible spectrophotometer) by measuring the change in absorbance at $260 \mathrm{~nm}$ with temperature. The spectrophotometrically determined melting curves were based on monitoring the change in A260nm with 
temperature over a range of $5^{\circ} \mathrm{C}$ to $110^{\circ} \mathrm{C}$ at a rate of $5.0^{\circ} \mathrm{C}$ increment The melting curve obtained was used determine $T_{m}$ values. Melting temperatures $\left(T_{m}\right)$ was determined by taking the point at half the curve height. ${ }^{24,25}$ The DNA experiment was performed by heating ctDNA $100 \mu \mathrm{l}(75 \mu \mathrm{g} / \mathrm{ml})$ in $0.01 \mathrm{M}$ Tris, $0.1 \mathrm{M} \mathrm{NaCl}$ at $\mathrm{pH} 7.34$ to $100^{\circ} \mathrm{C}$ and then the $5 \mu \mathrm{L}$ of rhodamine $\mathrm{B}(0.24 \mu \mathrm{M})$ was added and the $\mathrm{T}_{\mathrm{m}}$ was determined. Similarly, the experiment was performed again by heating the DNA $100 \mu \mathrm{l}(75 \mu \mathrm{g} / \mathrm{ml})$ to $100^{\circ} \mathrm{C}$ and then $5 \mu \mathrm{L}$ of rhodamine B $(0.24 \mu \mathrm{M})$ and $100 \mu \mathrm{l}$ AOLE $(17 \mathrm{mg} / \mathrm{ml})$ of AOLE were added and the $\mathrm{T}_{\mathrm{m}}$ was determined. ${ }^{26}$

\section{Molecular docking}

The starting geometry some AOLE contents was constructed using chem3D Ultra (version 8.0, Cambridge soft Com., USA). The optimized geometry of AOLE contents with the lowest energy was used in the molecular docking. Crystal structures of two DNA fragments with the B-form were downloaded from the Protein Data Bank (https://www.rcsb.org/structure/102D). The molecular dockings of AOLE contents with B-DNAs were accomplished by Auto Dock 4.2 software from the Scripps Research Institute (TSRI) (http:// autodock.scripps.edu/). Firstly, the polar hydrogen atoms were added into B-DNA molecules. Then, the partial atomic charges of the B-DNA and AOLE contents molecules were calculated using Kollman methods. ${ }^{27}$ In the process of molecular docking, the grid maps of dimensions ( $62 \AA$ X $62 \AA$ X $62 \AA$ ) with a grid-point spacing of $0.376 \AA$ and the grid boxes is centered. The number of genetic algorithm runs and the number of evaluations was set to 100 . All other parameters were default settings. Cluster analysis was performed on the results of docking by using a root mean square (RMS) tolerance of $2.0 \AA$, and this was dependent on the binding free energy. Lastly, the dominating configuration of the binding complex of AOLE contents and B-DNA fragments with minimum energy of binding can be determined.

\section{Results and discussion}

\section{Fluorometric findings}

Similar fluorescence emission data were obtained by either using genomic DNA or ctDNA. In Figure 1, the fluorescence spectrum of $\mathrm{RB}(0.24 \mu \mathrm{M})$ in the wavelength range of $560-650 \mathrm{~nm}$ excited at $550 \mathrm{~nm}$ in the presence of increasing AOLE concentrations is shown. On addition of AOLE, a hypochromic effect was observed by titration with no clear isosbestic point. Complex formation between RB and AOLE was confirmed by a decrease in fluorescence intensity with increasing AOLE concentration. This significant fluorescence change suggests a strong association between RB and the AOLE. In addition, data obtained from the fluorometric titrations are presented in inset of Figure 1 clearly demonstrating a stoichiometry titration pattern between RB and AOLE. Safitri et al. ${ }^{28}$ have shown that RB increases lipid peroxidation and can be used as an oxidative stress marker. Olive leaves contain many polyphenolic compounds such as oleuropein, hydroxytyrosol and flavonoids, including luteolin, rutin, caffeic acid, catechin and apigenin. Oleuropein, together with other closely related compounds such as 10-hydroxyoleuropein, ligstroside and 10-hydroxyligstroside, are tyrosol esters of elenolic acid. ${ }^{29,30}$

The total phenolic contents of the olive leaves aqueous extract was expressed and presented in terms of $\mathrm{mg}$ gallic acid/g extracts. The obtained results showed that the amount of phenolic compounds of the olive leaf was $122.2 \pm 1.20 \mathrm{mg}$ gallic acid/g. Most of these compounds are powerful antioxidant agents present abundantly in olive leaves and hence can reduce the oxidative stress produced by $\mathrm{RB}$ in a ratio of $1: 1$ as shown by stoichiometry titration. The antioxidant activity of aqueous olive leaf extract was evaluated using the 2,2-diphenyl1-picrylhydrazyl (DPPH) assay and the $\mathrm{IC}_{50}$ was $65 \pm 2.3 \mu \mathrm{g} / \mathrm{ml}$, lower than the value of vitamin $\mathrm{C}(59.45 \mu \mathrm{g} / \mathrm{mL}){ }^{31}$ The reducing ability of the AOLEs serve as an important indicator of its potential antioxidant activity, because its associated with their ability to donate electron to free radical species, reducing them into more stable and un-reactive form. The reducing power of the AOLEs increased with concentration but it was below the reducing power capacity of ascorbic acid. The obtained result is in a good agreement with Ferreira et al..$^{32}$ who investigated the reducing power of olive leaf extract using the ferricyanide assay. Based on Phan et al. ${ }^{33}$ studies the chemical structure of polyphenols and RB, the distribution of hydroxyl groups on polyphenols as well as the presence of a carboxyl group in RB can influence interactions through the formation of hydrogen bonds and the partitioning of polyphenols in a non-polar core of RB will facilitate the hydrophobic interaction..$^{33}$

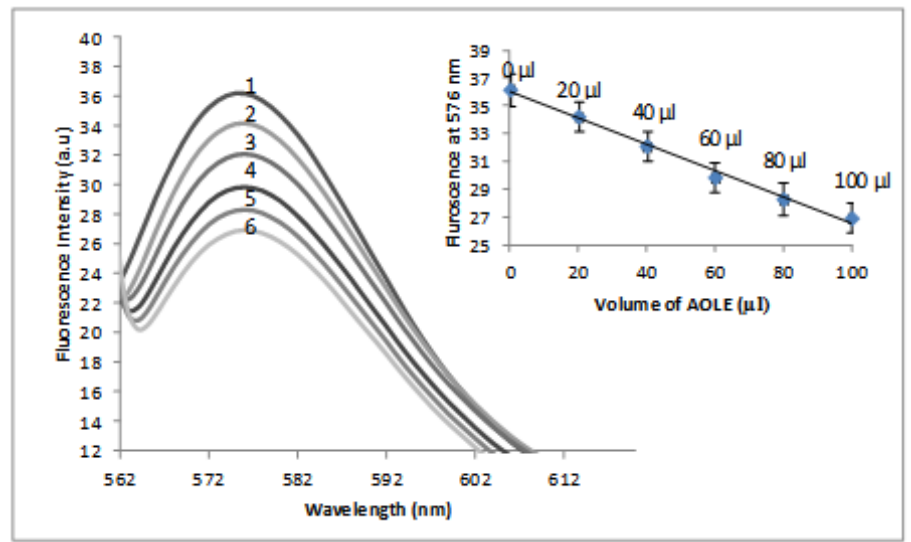

Figure I Plot of fluorescence emission of RB $(0.24 \mu \mathrm{M})$ vs wavelength from $562-650 \mathrm{~nm}$ using excitation $\lambda_{550 \mathrm{~nm}}$ in the presence of different volumes of AOLE $(5 \mathrm{~g} / 15 \mathrm{ml})$ in $0.01 \mathrm{M}$ Tris, $0.1 \mathrm{M} \mathrm{NaCl}$ at $\mathrm{pH}$ 7.34. Inset: Fluorescence intensity at $576 \mathrm{~nm}$ plotted versus different volumes of AOLE $(5 \mathrm{~g} / \mathrm{I} 5 \mathrm{ml})$ in $0.01 \mathrm{M}$ Tris, $0.1 \mathrm{M} \mathrm{NaCl}$ at $\mathrm{pH} 7.34$ and $\mathrm{R}^{2}$ was 0.9931 . The volumes of AOLE

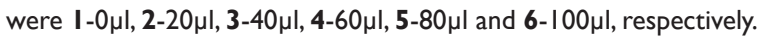

Figure 2 shows a decrease in fluorescence intensity of RB $(0.24 \mu \mathrm{M})$ in $0.01 \mathrm{M}$ Tris, $0.1 \mathrm{M} \mathrm{NaCl}$ at $\mathrm{pH} 7.34$ on addition of ctDNA (system A). This change in fluorescence intensity of RB in presence of ct-DNA is indicative of a strong association of RB to DNA and suggesting the location of the bound RB in a hydrophobic environment. As described in the literature, RB can more easily bind if their association to double stranded DNA is facilitated by positive charges. DNA attracts counter ions to its surface to screen polyionic charges on the phosphodiester backbone. RB may compete with sodium ions for binding to DNA phosphates which further stabilizes the RB-DNA complex. It is observed that in high salt concentrations the binding of RB to the DNA phosphate backbone decreases and the binding constant decreases moderately. ${ }^{34}$ In addition, the binding of $\mathrm{RB}$ to the minor groove of DNA was further indicated by circular dichroism, fluorescence quenching, and molecular docking studies. ${ }^{25,34}$ On addition of $100 \mu 1$ of AOLE (stock: $5 \mathrm{~g} / 15 \mathrm{ml}$ ), a further reduction in RB fluorescence intensity was seen due to the interaction between free unbound RB and AOLE as mentioned above. The inset of Figure 
2 shows differences in the fluorescence intensities of system $\mathbf{A}$ and system $\mathbf{B}$. Fluorescence intensity of the system $\mathbf{B}$ is higher than that of the system $\mathbf{A}$ because the AOLE did not allow the RB to interact with the ct-DNA and more free (unbound) RB is exposed to the excitation light and then produces more emission fluorescence light.

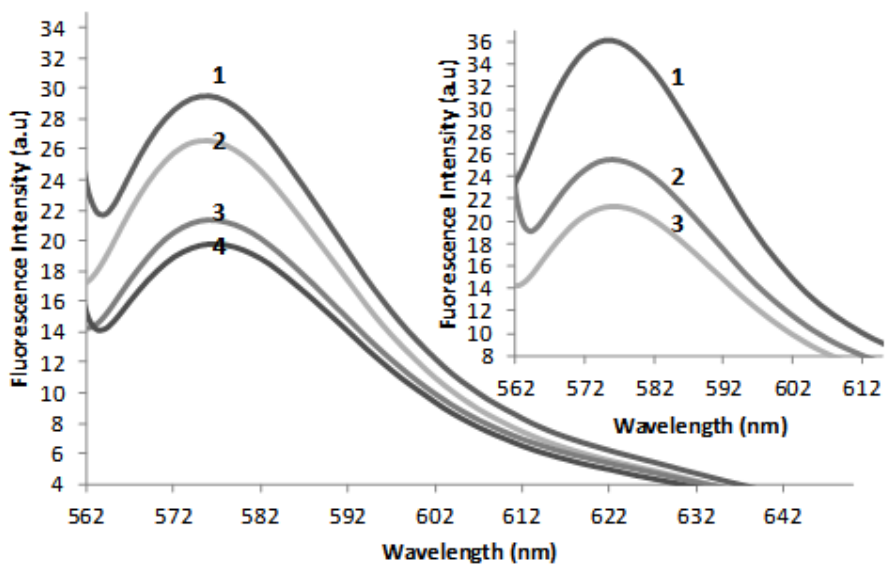

Figure 2 Plot of fluorescence emissions from $562-650 \mathrm{~nm}$ vs wavelength using excitation $\lambda 550 \mathrm{~nm}$ of: I- I $0 \mu \mathrm{IRB}(0.24 \mu \mathrm{M})$ and $1990 \mu \mathrm{I} 0.01 \mathrm{M}$ Tris, $0.1 \mathrm{M} \mathrm{NaCl}$ at $\mathrm{pH}$ 7.34. 2-I $0 \mu \mathrm{L} \mathrm{RB}(0.24 \mu \mathrm{M}), \mathrm{I} 890 \mu \mathrm{I} 0.0 \mathrm{I}$ MTris, $0 . \mathrm{I} \mathrm{M} \mathrm{NaCl}$ at $\mathrm{pH} 7.34$ and $100 \mu \mathrm{l} \mathrm{ctDNA}(75 \mu \mathrm{g} / \mathrm{ml}) .3-10 \mu \mathrm{l} B(0.24 \mu \mathrm{M}), \mathrm{I} 790 \mu \mathrm{l} 0.0 \mathrm{l}$ MTris, 0.I M $\mathrm{NaCl}$ at $\mathrm{pH} 7.34, \mathrm{I} 00 \mu \mathrm{l} \mathrm{ctDNA}(75 \mu \mathrm{g} / \mathrm{ml})$ and I $00 \mu \mathrm{l}$ AOLE $(17 \mathrm{mg} / \mathrm{ml}) .4-10$ $\mu$ I RB $(0.24 \mu \mathrm{M}), \mathrm{I} 690 \mu \mathrm{l} 0.0 \mathrm{I} \mathrm{M}$ Tris, $0.1 \mathrm{M} \mathrm{NaCl}$, at pH 7.34, $100 \mu \mathrm{l}$ ctDNA $(75 \mu \mathrm{g} / \mathrm{ml})$ and $200 \mu \mathrm{l}$ AOLE $(34 \mathrm{mg} / \mathrm{ml})$. Inset: Fluorescence spectra of I- 10 $\mu \mathrm{l} \mathrm{RB}(0.24 \mu \mathrm{M})$ and $1990 \mu \mathrm{l} 0.0 \mathrm{I} \mathrm{M}$ Tris, $0 . \mathrm{I} \mathrm{M} \mathrm{NaCl}$ at $\mathrm{pH} 7.34,2$ - System $B$ formation was induced by sequential addition of aliquots of Tris buffer, RB, AOLE and finally ct-DNA. 3-System A: formation was induced by sequential addition of aliquots of Tris buffer, RB, ct-DNA and finally AOLE.

The antigenotoxic effect obtained in this study is in agreement with many literature studies. ${ }^{30}$ Cabarkapa et al.${ }^{35}$ found that the excessive release of stress hormone adrenaline is accompanied by generation of reactive oxygen species which may cause disruption of DNA integrity leading to cancer and age-related disorders. Phenolic-rich plant product dry olive leaf extract was reported to attenuate formation of DNA lesions induced by adrenaline. It has also been found that the antigenotoxic effect of the extract was more pronounced at smaller concentrations and post-treatment with $0.125 \mathrm{mg} / \mathrm{ml}$ dry olive leaf extract was the most effective against adrenaline genotoxicity. ${ }^{35}$ Topalovic et al. ${ }^{36}$ have also reported that thyroid hormones change the rate of basal metabolism, modulating the consumption of oxygen and causing production of reactive oxygen species, which leads to the development of oxidative stress and DNA strand breaks. ${ }^{36}$ Olive (Olea europaea L.) leaf contains many potentially bioactive compounds, making it one of the most potent natural antioxidants. These findings indicate that L-thyroxine exhibit genotoxic effects and that olive leave extract displayed a protective effect against thyroxine-induced genotoxicity. This feature can also be explained by its capacity to act as a potent free radical scavenger. ${ }^{36}$

\section{Structural features of duplex DNA with Olea europaea leave extracts}

The melting temperature $\left(\mathrm{T}_{\mathrm{m}}\right)$ of $\mathrm{ctDNA}\left(88.0 \pm 0.2^{\circ} \mathrm{C}\right)$, which is defined as the temperature at which half of the double-stranded DNA is dissociated into single strands, is strictly related to the stability of the DNA. In addition, the binding of RB to ctDNA has increased the $\mathrm{T}_{\mathrm{m}}$ by $4.0 \pm 0.06^{\circ} \mathrm{C}$ due to increase the intercalation ability between the two DNA strands and this consistent what has been noticed by Masum et al. ${ }^{12}$ The intercalation of RB into the double helix has increased the helix melting temperature and stabilize the natural structure of DNA, and thus lead to the $\mathrm{T}_{\mathrm{m}}$ of DNA increase of about $4.0 \pm 0.06^{\circ} \mathrm{C}$, while the intercalative binding of AOLE components lead to the $\mathrm{T}_{\mathrm{m}}$ of ctDNA increase of about $0.52 \pm 0.03^{\circ} \mathrm{C}$. It can be seen that the $\mathrm{T}_{\mathrm{m}}$ of $\mathrm{DNA}$ with $\mathrm{RB}$ and AOLE components has a $\mathrm{T}_{\mathrm{m}}$ of $88.5^{\circ} \mathrm{C}$ which is nearly similar to the $\mathrm{T}_{\mathrm{m}}$ of ctDNA alone $\left(88.0 \pm 0.2^{\circ} \mathrm{C}\right)$ and this suggesting that the AOLE components has abolished the RB intercalated ability.

\section{Molecular docking analysis}

Table 1 shows the energies of binding of the some AOLE contents of with DNAs fragments obtained by using molecular docking strategy. In this study, the molecular dockings of AOLE contents with two B-DNA fragments were performed using Auto Dock 4.2 to understand the binding mode of AOLE contents with B-DNA and to obtain the information about interaction forces between Rhodamine, AOLE contents and DNA. Rhodamine and AOLE contents were kept as flexible molecule and was docked into two types of rigid B-DNA fragments to obtain the preferential binding site AOLE contents on B-DNAs and the molecular docking results were shown in Table 1. It can be found from Table 1 that the more adenine (A) and thymine (T) base pairs in DNA sequence is, the more negative the binding energy (DG) is to some extent, indicating that AOLE contents prefers to bind on the minor groove of A-T rich DNA fragments as shown in Table 1. This is because the narrower and deeper shape of the minor groove can offer several sites of action during the binding process of AOLE contents with DNAs, resulting in the close contact with the surface of AOLE contents through van der Waals forces and hydrogen bonding interaction. Meanwhile, it can be found that the significant change of conformation of AOLE contents be present in the AOLE contentsDNA complexes to orient easily along the minor groove.

The conformation change of AOLE contents is close relation with the structure of minor groove of DNA fragments as shown in Table 1. It is implied that the flexibility of AOLE contents molecule also plays an important role in the binding process of Rhodamine and AOLE contents with DNA. In addition, it can be found that there are van der Waals, hydrogen bonding and electrostatic interactions between Rhodamine, AOLE contents and DNAs and the contribution of van der Waals and hydrogen bonding interaction is much greater than that of the electrostatic interaction because the sum of van der Waals energy, hydrogen bonding energy and desolvation free energy is larger than the electrostatic energy (Table 1), which is consistent with the experimental results. As indicated in the literature, the binding mode of Rhodamine B on DNA is groove binding as the interaction mode. ${ }^{37}$ The fluorescence emission intensity of system A (in which the formation of the system was formed by sequential addition of aliquots of Tris buffer, RB, ct-DNA and finally AOLE, Figure 2) did not change on further addition of AOLE and this suggesting that there is no competitive binding interaction between RB and AOLE on ct-DNA. Therefore, it can be concluded that the binding mode of Rhodamine on ct-DNA is major groove binding interaction but the AOLE is mainly minor groove binding interaction. 
Table I Various energies in the binding process of the some AOLE contents of with DNAs obtained from molecular docking.The unit of all energies was $\mathrm{kJ} / \mathrm{mol}$

\begin{tabular}{|c|c|c|c|c|c|c|c|c|c|}
\hline \multirow[b]{2}{*}{ Ligand } & \multicolumn{2}{|c|}{$\begin{array}{l}\text { DNA PBD ID(I 02d) } \\
\text { d(CGCAAATTTGCG })^{2}\end{array}$} & \multicolumn{2}{|c|}{$\begin{array}{l}\text { DNA PBD ID(Ibna) } \\
\text { d(CGCGAASSCGCG)2 }\end{array}$} & \multirow[b]{2}{*}{ Ligand } & \multicolumn{2}{|c|}{$\begin{array}{l}\text { DNA PBD ID }(102 d) \\
\text { d(CGCAAATTTGCG) }\end{array}$} & \multicolumn{2}{|c|}{$\begin{array}{l}\text { DNA PBD ID(I bna) } \\
\text { d(CGCGAASSCGCG) }\end{array}$} \\
\hline & $\begin{array}{l}\text { Binding } \\
\text { energy } \\
\Delta \mathbf{G}^{\mathrm{a}}\end{array}$ & Binding site & $\begin{array}{l}\text { Binding } \\
\text { energy } \\
\Delta \mathbf{G}^{\mathrm{a}}\end{array}$ & $\begin{array}{l}\text { Binding } \\
\text { site }\end{array}$ & & $\begin{array}{l}\text { Binding } \\
\text { energy } \\
\Delta \mathbf{G}^{\mathrm{a}}\end{array}$ & Binding site & $\begin{array}{l}\text { Binding } \\
\text { energy } \Delta \mathbf{G}^{\mathrm{a}}\end{array}$ & $\begin{array}{l}\text { Binding } \\
\text { site }\end{array}$ \\
\hline Rhodamine & -3.37 & Major G & -3.46 & Major G & Nuzhenide & -3.74 & Major G & $-3.5 I$ & Minor G \\
\hline Catechin & -7.85 & Minor & -7.64 & Minor & Hydroxytyros & -4.46 & Minor G & -4.79 & Minor G \\
\hline $\begin{array}{l}\text { 5-Caffeoylquinic } \\
\text { acid }\end{array}$ & -5.05 & Minor G & -4.46 & Minor G & $\begin{array}{l}\text { Homovanillic } \\
\text { acid }\end{array}$ & -3.84 & Minor G & -4.18 & Minor G \\
\hline $\begin{array}{l}\text { Cyanidin-3 } \\
\text { glucoside }\end{array}$ & -7.21 & Minor G & $-7.5 I$ & Minor G & Vanillic acid & -2.89 & Minor G & -3.85 & Minor G \\
\hline $\begin{array}{l}\text { Dimethyloleu- } \\
\text { ropein }\end{array}$ & -4.69 & Minor G & -2.91 & Minor G & Tyrosol & -4.68 & Minor G & -5.03 & Minor G \\
\hline $\begin{array}{l}\text { 3,4-DHPEA- } \\
\text { EDA }\end{array}$ & -3.79 & Minor G & -1.87 & Minor G & Rutin & -7.23 & Minor G & -7.32 & Minor G \\
\hline Hesperidin & -7.98 & Minor G & -7.73 & Minor G & Oleuroside & -5.07 & Minor G & -4.74 & Minor G \\
\hline Luteolin & -8.69 & Minor G & -7.74 & Minor G & Ligstroside & -5.36 & Minor G & -6.45 & Minor G \\
\hline Quercetin & -8.02 & Minor G & -7.54 & Minor G & Apigenin & -8.16 & Minor G & -8.27 & Minor G \\
\hline Verbascoside & -5.09 & Minor G & -2.62 & Minor G & Caffeic acid & -4.02 & Minor G & -4.78 & Minor G \\
\hline
\end{tabular}

${ }^{a} \Delta \mathrm{G}$ is the binding free energy change in the binding process

\section{Conclusion}

The present study created convincing evidence that AOLE has a protective effect against chemically induced genotoxicity and oxidative damage. The genoprotective activity could be exhibited through an increase in antioxidant activity, scavenging of free radicals and inhibition of oxidative stress. These findings indicate genoprotective and antioxidant properties in olive leaf extract, strongly supporting further explorations of its underlying mechanisms of action.

\section{Acknowledgement}

None.

\section{Conflict of interest}

The authors declare that the research was conducted in the absence of any commercial or financial relationships that could be construed as a potential conflict of interest.

\section{References}

1. Pati H, Howard T, Townes H, et al. Unexpected syntheses of secocyclopropyltetrahydroquinolines-from a radical 5-exo-trig cyclization reaction: analogs of $\mathrm{CC}-1065$ and the duocarmycins. Molecules. 2004;9(3):125-133.

2. Wanunu M, Sutin J, Meller A. DNA profiling using solid-state nanopores: detection of DNA-binding molecules. Nano Lett. 2009;9(10):3498-3502.

3. Probst M, Aeschimann W, Chau TT, et al. Structural insight into DNAassembled oligochromophores: crystallographic analysis of pyrene- and phenanthrene-modified DNA in complex with BpuJI endonuclease. Nucleic Acids Res. 2016;44(15):7079-7089.

4. Chen RJ, Zhang Y. Controlled precipitation of solubilized carbon nanotubes by delamination of DNA. J Phys Chem B. 2006;110(1):54-57.
5. Ikhlas S, Ahmad M. Binding studies of guggulsterone-E to calf thymus DNA by multi-spectroscopic, calorimetric and molecular docking studies. Spectrochim Acta A Mol Biomol Spectrosc. 2018;190:402-408.

6. Saibabu V, Singh S, Ansari MA, et al. Insights into the intracellular mechanisms of citronellal in Candida albicans: implications for reactive oxygen species-mediated necrosis, mitochondrial dysfunction, and DNA damage. Rev Soc Bras Med Trop. 2017;50(4):524-529.

7. Parodi $\mathrm{S}$, Taningher M, Russo $\mathrm{P}$, et al. DNA-damaging activity in vivo and bacterial mutagenicity of sixteen aromatic amines and azo-derivatives, as related quantitatively to their carcinogenicity. Carcinogenesis. 1981;2(12):1317-1326.

8. Wess JA, Archer DL. Disparate in vivo and in vitro immunomodulatory activities of rhodamine B. Food Chem Toxicol. 1982;20(1):9-14.

9. Parodi S, Zunino A, Ottaggio L, et al. Lack of correlation between the capability of inducing sister-chromatid exchanges in vivo and carcinogenic potency, for 16 aromatic amines and azo derivatives. Mutat Res. 1983;108(1-3):225-238.

10. Mizuno N, Fujiwara A, Morita E. Effect of dyes on the photodecomposition of pyridoxine and pyridoxamine. JPharm Pharmacol. 1981;33(6):373-376.

11. Safitri YA, Indrawan IWA, Winarsih S. Rhodamine B induces oxidative stress and cervical epithelial cell proliferation in the uterus. Toxicol Rep. 2015;2:1434-1436.

12. Masum AA, Chakraborty M, Pandya P, et al. Thermodynamic study of rhodamine 123-calf thymus DNA interaction: determination of calorimetric enthalpy by optical melting study. J Phys Chem B. 2014;118(46):13151-13161.

13. Mylonaki S, Kiassos E, Makris DP, et al. Optimisation of the extraction of olive (Olea europaea) leaf phenolics using water/ethanol-based solvent systems and response surface methodology. Anal Bioanal Chem. 2008;392(5):977-985. 
14. Koca U, Suntar I, Akkol EK, et al. Wound repair potential of Olea europaea L. leaf extracts revealed by in vivo experimental models and comparative evaluation of the extracts' antioxidant activity. J Med Food. 2011;14(1-2):140-146.

15. Manna C, Migliardi V, Golino P, et al. Oleuropein prevents oxidative myocardial injury induced by ischemia and reperfusion. J Nutr Biochem. 2004;15(8):461-466.

16. Cumaoglu A, Rackova L, Stefek M, et al. Effects of olive leaf polyphenols against $\mathrm{H}_{2} \mathrm{O}_{2}$ toxicity in insulin secreting beta-cells. Acta Biochim Pol. 2011;58(1):45-50.

17. Cumaoglu A, Ari N, Kartal M, et al. Polyphenolic extracts from Olea europea L. protect against cytokine-induced beta-cell damage through maintenance of redox homeostasis. Rejuvenation Res. 2011;14(3):325-334.

18. Bali EB, Ergin V, Rackova L, et al. Olive leaf extracts protect cardiomyocytes against 4-hydroxynonenal-induced toxicity in vitro: comparison with oleuropein, hydroxytyrosol, and quercetin. Planta Med. 2014;80(12):984-992.

19. Johns MB, Paulus Thomas JE. Purification of human genomic DNA from whole blood using sodium perchlorate in place of phenol. Anal Biochem. 1989;180(2):276-278

20. Islam MM, Basu A, Hossain M, et al. Enhanced DNA binding of 9-omegaamino alkyl ether analogs from the plant alkaloid berberine. DNA Cell Biol. 2011;30(2):123-133.

21. Islam MM, Sinha R, Kumar GS. RNA binding small molecules: studies on t-RNA binding by cytotoxic plant alkaloids berberine, palmatine and the comparison to ethidium. Biophys Chem. 2007;125(2-3):508-520.

22. Ainsworth EA, Gillespie KM. Estimation of total phenolic content and other oxidation substrates in plant tissues using Folin-Ciocalteu reagent. Nat Protoc. 2007;2(4):875-877.

23. Shirzad H, Niknam V, Taheri M, et al. Ultrasound-assisted extraction process of phenolic antioxidants from Olive leaves: a nutraceutical study using RSM and LC-ESI-DAD-MS. J Food Sci Technol. 2017;54(8):2361-2371.

24. Davies J. Inactivation of the antibiotics and the dissemination of resistance genes. Science. 1994;264(5157):375-382.

25. Al Masum A, Chakraborty M, Ghosh S, et al. Biochemical activity of a fluorescent dye rhodamine 6G: Molecular modeling, electrochemical, spectroscopic and thermodynamic studies. J Photochem Photobiol B. 2016;164:369-379.
26. Houssier C, Depauw Gillet MC, Hacha R, et al. Alteration in the nucleosome and chromatin structures upon interaction with platinum coordination complexes. Biochim Biophys Acta. 1983;739(3):317-325.

27. Tiwari R, Mahasenan K, Pavlovicz R, et al. Carborane clusters in computational drug design: a comparative docking evaluation using AutoDock, FlexX, Glide, and Surflex. J Chem Inf Model. 2009;49(6):1581-1589.

28. Safitri YA, Indrawan IWA, Winarsih S. Rhodamine B induces oxidative stress and cervical epithelial cell proliferation in the uterus. Toxicol Rep. $2015 ; 2: 1434-1436$

29. Velazquez-Palmero D, Romero-Segura C, Garcia-Rodriguez R, et al. An Oleuropein beta-Glucosidase from Olive Fruit Is Involved in Determining the Phenolic Composition of Virgin Olive Oil. Front Plant Sci. 2017;8:1902.

30. Qabaha K, Al Rimawi F, Qasem A, et al. Oleuropein Is Responsible for the Major Anti-Inflammatory Effects of Olive Leaf Extract. J Med Food. 2018;21(3):302-305.

31. Gong Y, Fang F, Zhang X, et al. B Type and Complex A/B Type Epicatechin Trimers Isolated from Litchi pericarp Aqueous Extract Show High Antioxidant and Anticancer Activity. Int J Mol Sci. 2018;19(1):301.

32. Ferreira ICFR, Barros L, Soares ME, et al. Antioxidant activity and phenolic contents of Olea europaea L. leaves sprayed with different copper formulations. Food Chemistry. 2007;103(1):188-195.

33. Phan HT, Yoda T, Chahal B, et al. Structure-dependent interactions of polyphenols with a biomimetic membrane system. Biochim Biophys Acta. 2014;1838(10):2670-2677.

34. Adhikary A, Jena HS, Konar S. A family of $\mathrm{Fe}^{3+}$ based double-stranded helicates showing a magnetocaloric effect, and Rhodamine B dye and DNA binding activities. Dalton Trans. 2015;44(35):15531-15543.

35. Cabarkapa A, Zivkovic L, Zukovec D, et al. Protective effect of dry olive leaf extract in adrenaline induced DNA damage evaluated using in vitro comet assay with human peripheral leukocytes. Toxicol In Vitro. 2014;28(3):451-456.

36. Topalovic DZ, Zivkovic L, Cabarkapa A, et al. Dry olive leaf extract counteracts L-thyroxine-induced genotoxicity in human peripheral blood leukocytes in vitro. Oxid Med Cell Longev. 2015;8p.

37. Hegde AH, Prashanth SN, Seetharamappa J. Interaction of antioxidant flavonoids with calf thymus DNA analyzed by spectroscopic and electrochemical methods. J Pharm Biomed Anal. 2012;63:40-46. 